\title{
CELEBRATING 165 YEARS OF COLLABORATION BETWEEN THE ANASTASIE FATUU BOTANICAL GARDEN AND THE NATURAL SCIENCES SCHOOL FROM IAŞI
}

\author{
Cătălin TĂNASE*1, Ciprian Constantin BÎRSAN², Ana COJOCARIU², \\ Cristiana Virginia PETRE ${ }^{2}$, Constantin MARDARI ${ }^{2}$

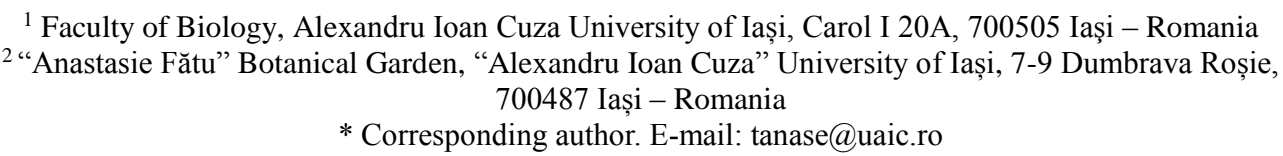

Besides ex situ conservation of plant species, the mission of the Botanical Garden of "Alexandru Ioan Cuza" University of Iaşi is to offer the opportunity to learn about native and exotic plant species, and to promote new perspectives for ecological education. Since its foundation, the institution plays a very important role in the didactic activity related to plants research and conservation and offers excellent conditions for the student field practice for the Faculties of Biology, Geography-Geology, Agronomy, Horticulture, Medicine, Pharmacy, Architecture, etc. Along its 165 years existence, numerous personalities carried out didactic activities in the Botanical Garden while using it as a valuable educational resource, thus establishing a fruitful relationship with the academic community. This article presents the scientific and didactic activity (depending on the scientific field) related to the Botanical Garden of all those personalities as well as their contribution to the permanent development of the institution.

\section{Botany}

Botanical Garden - academic environment relationships were firstly established by the founder of this institution, dr. Anastasie Fătu (1816-1886), professor of Botany at the Faculty of Sciences from the University of Iaşi (since 1874), and member of the Romanian Academy (since 1871). He was also one of the founders of the Faculty of Medicine (1879), which, at that time was a part of the University of Iaşi. By founding the Botanical Garden, Professor Fătu tried and succeeded, among others, “...to encourage young students to learn botany...”, and to offer a valuable educational resource for the didactic activity. Thus, the plant species "from Fătu's garden" were presented by Professor Dimitrie Brândză to the students attending the botany courses as living didactic material. He published the first catalog with the plants in the Botanical Garden (1871) including over 2,500 species of native and also of some exotic genera Enumeraţiunea specieloru de plante cultivate în Grădina Botanică din Iassy (Enumeration of the plant species cultivated in the Botanical Garden of Iasi). In this work, he adopted the Latin nomenclature, presented a classification system in concordance with the taxonomical principles of that time, and also the plant names as they were known by Romanian people.

Moreover, Professor A. Fătu is the author of first university textbook of botany Elemente de botanică: Histologia, Organographia şi Phyisiologia vegetală (Botanic notions: histology, organography and plant physiology), with the first part, published in Iaşi (1880), including aspects of cytology, histology, organography and plant physiology, and the second part comprising elements of plant taxonomy and plant geography, remaining as manuscript - 
Taxonomia, Phytographia şi Geographia Botanică [TOMA, 2015; TĂNASE \& al. 2016]. By synthetizing the whole international scientific literature of that time, this epochal work [POP, 1967] represented the main source of information, and significantly contributed to the educational process of students in the fields of natural sciences, medicine or agronomy at the end of the nineteenth century.

His remarkable didactic career was preceded by studies in Vienna and Paris, where he was granted two $\mathrm{PhD}$ degrees: in philosophy and law sciences (1841) as well as in medicine (1846). In turn, the great professor encouraged the young students to go and specialize abroad, at well-known universities, in various scientific domains [AIFTINC $\breve{A}, 2014$ ], by founding, together with dr. Ion Ionescu de la Brad, the Society for encouraging Romanian youth to study abroad (1855). His scientific activity was internationally recognized, and, consequently Professor Fătu became member in Silesian Society for science development and Society of Natural Sciences of Frankfurt. Professor Fătu had also an active political activity, before the union of the Romanian Principalities, and after that. He was the president of the Assembly of Deputies (1868), and, in 1869 was elected senator. Besides the political activity, he had a significant contribution in organization of the medical and social assistance in Moldova, in elaborating, applying and organizing the public health domain. The scientific and cultural activity of dr. Anastasie Fătu was materialized in approximately 3000 pages published in 40 years of activity [ZAMFIR, 1987].

Contemporary with dr. Anastasie Fătu was the great Professor, physician and botanist dr. Dimitrie Brandză (1846-1895) who organized (1872) a second Botanical Garden in the courtyard of the Museum of the Society of Physicians and Naturalists in Iaşi. In this new location were planted species from the garden of Anastasie Fătu as well as species obtained from seeds collected by the botanist Iosif Szabó from different regions of the country; some of the initial trees are still existing today. The plants from Botanical Garden and herbarium sheets were used by Professor Brandză to illustrate his botany courses at the Faculty of Natural Sciences of the University of Iaşi, courses appreciated as solemn and of high academic level [TOMA, 2015]. In 1874 he was transferred to the Botany and Zoology department of the Sciences Faculty from Bucharest, but in the short time he spent in Iaşi he carried out a fruitful activity as professor, researcher, and medic. Starting with 1875 he coordinated the organization of the Botanical Garden of the University of Bucharest, institution bearing the name of the great Professor (since 1994). He founded the first Botanical Museum which harbored the Herbarium of Romanian Flora. He is also the founder of the Institute of Botany, inaugurated in 1892, with the first academic course of botany [ZANOSCHI \& TOMA, 1995].

He studied medicine and natural sciences at the Sorbonne University in Paris, and had a remarkable scientific activity. His fundamental work - Prodromul florei române sau Enumeraţiunea plantelor până azi cunoscute în Moldova şi Valachia (The Conspectus of Romanian flora or the Enumeration of the plant species known until today in Moldova and

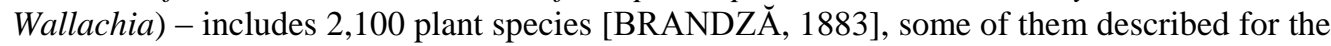
first time, and represents the first critical and synthetic analysis of Romanian flora. As a recognition of his contributions to the knowledge of Romanian flora, of his scientific and academic activity, in 1879 he was elected full member of the Romanian Academy. He had an active implication in evolution of the "Scientific Section" of the Academy, and between 1893 and 1895, he was elected vice-president of the same institution. In addition, some plant, fungi as well as a fossil, were named after the great researcher and Professor Dimitrie Brandză, by great scientific personalities as Henri-Ernest Baillon, Adrien Réne Franchet, Iuliu Prodan etc. 
In 1876, Professor dr. Cristea Buicliu (1857-1916), tried to organize a third botanical garden around the University of Iaşi (currently, the University of Medicine and Pharmacy). He was a medicine doctor who studied in Paris and a prominent figure of the medical science in Romania, and, in this endeavor collaborated with dr. Anastasie Fătu. He was a university professor at the Faculty of Medicine from Bucharest at the department of internal medicine, and coordinated the medical clinic of the Brâncovenesc hospital.

Since 1895 until 1936, Professor dr. Alexandru Popovici (1866-1941) held the Botany courses at the Faculty of Sciences within the University of Iaşi, where he re-organized the Laboratory of Botany, the Herbarium, and the Library. Besides his prestigious academic activity, he was preoccupied by the foundation of a new university botanical garden, taking into consideration the importance of living plant collections in the academic education process. His initial intention was to create a new botanical garden in the vicinity of the Administrative Palace, (currently the Palace of Culture). Although the plans for this garden were designed (including the construction of a central greenhouse complex and a Botanical Institute) and despite the efforts of Professor Popovici, his idea was not materialized because of the lack of funds [MITITIUC \& TONIUC, 2006]. Still, he was not discouraged, and surrounded by a small but enthusiastic team of collaborators, started the first plantings on a terrain situated near the University. He was the director of the Botanical Garden from the University Palace (currently Titu Maiorescu Dendrological Park), institution he organized and coordinated between 1921 and 1936. The garden included a greenhouse for tropical species which endures even today. The Popovici Garden [TOMA, 2015] represented for over 40 years the most valuable resource for the botanical academic education in the city of Iaşi.

For his researches focused on plant cytology, he was granted a $\mathrm{PhD}$ degree at the University of Bonn. For over 40 years he taught Botany and was one of the most active professors at the University of Iaşi. He was one of the founders of the publication Annales scientifiques de l'Université de Jassy (1900). The scientific activity of Professor Alexandru Popovici was preponderantly focused on mycology; he published over 500 species of fungi from the historical region of Moldova. As a recognition of his experience and the high value of his research, he was elected member in the Mycological Society of France and honorary member of the Romanian Academy [IACOB, 2011].

Closely working with Alexandru Popovici on organizing the botanical garden near the University Palace was head of works Constantin Petrescu (1879-1936), botanist and mycologist at the Faculty of Sciences within the University of Iași, directly involved in the plantation activities and in diversifying the plant collections. He was assigned to travel to various steppe habitats all across Romania to gather spontaneous plant species and to bring from the Botanical Garden of Cluj trees and shrubs for the new botanical garden [BURDUJA, 1979].

As a researcher, his main domains of interest were the flora and the micromycetes of Moldova and Dobrogea, but he also visited several locations in Muntenia and Oltenia, identifying and collecting numerous rare and unique plants and fungi, which were included in his personal Herbarium and used as teaching material for students. He showed tenacity and passion and decisively contributed to the enrichment of both botanical and mycological data regarding many rare plant species and host pathogen systems [BURDUJA \& MIHAI, 19761977].

Between 1937 and 1958, the activities in Botanical Garden were coordinated by Professor dr. Constantin Papp (1896-1972). They were mainly focused on development of this institution through plant collections enrichment, through trades with similar institutions from the country and abroad, especially after the Second World War when the Garden was 
almost entirely destroyed. In this regard, he elaborated a reconstruction plan, repaired some greenhouses and built a new one. He restored the outdoor plant collections and reorganized all of the garden's sections. Always, his Botany courses were illustrated with an impressive living botanic material from the Botanical Garden, institution he considered fundamental for teaching Biology at academic level.

In his impressive didactic and research career, Professor Constantin Papp was mainly preoccupied by the taxonomy of bryophytes and plant species as well as by the communities edified by these organisms. His remarkable researches started with his $\mathrm{PhD}$ dissertation focused on study the bryophyte species in Moldova (1926), and continued by the publication of the first identification keys for these organisms in Romania - Flora pentru determinarea briofitelor din Moldova (Flora for the identification of bryophytes in Moldova) in 1943, and the monograph on Briofitele din România (The bryophytes of Romania) in 1970, which remained for a long time the only reference book on these organisms in the country [MITITELU \& TOMA, 1988]. He approached also studies on cormophyte taxonomy, among which, the most valuable is the Monographie der Europäischen Arten der Gattung Melica L. (Monography of the European species of genus Melica L.), published in 1933. His vast experience was also valued during the elaboration of the monumental botanic monograph Flora R.S. România, vol. 12 (Flora R.S. Romania, tome 12). For his contribution to the above mentioned scientific domains, he is considered the greatest Romanian bryologist, while two plant species were named in his honor [TOMA, 2015].

Professor dr. Constantin Burduja (1906-1983) continued the activity of his illustrious predecessor and mentor, and coordinated, as director, the activities of the Botanical Garden between 1958 and 1962. He was mainly preoccupied to extend the garden, to enrich the plant collections especially in the Systematic section, to ex-situ conserve some rare plant species from Eastern and Southeastern Romania and to intensify the international exchange with similar institutions [MITITELU \& TOMA, 1983]. Professor Burduja can be considered as one of the founders of the current Botanical Garden, being designated by decision of the Rector of the University (1959) as the scientific coordinator of the new botanical garden which was to be established on the Copou Hill [TOMA \& TONIUC, 1984].

He was a very exigent teacher, very documented, and for many decades he taught the Botany, Pharmaceutical Botany, Geobotany, Plant Ecology and Plant Morphology courses. The prodigious scientific activity of Professor Burduja was focused on floristic and phytosociological studies, chorology of some threatened species, history of botany in Romania, and nature conservation. He initiated the first researches on the morphology and anatomy of plants at the University of Iaşi, and was mentor for many students and collaborators who will become great personalities in this field [TOMA, 2015]. He was President of the Subcommission of Nature Monuments and a significant contributor to Flora Romaniae Exsiccata and Flora Moldaviae and Dobrogeae Exsiccata.

Associate Professor dr. Constantin Dobrescu (1912-1990) coordinated the activity of the Botanic Garden for a short (1962-1963) but very important time, respectively the transfer of the institution from near the University to its current location. Distinguished teacher, meticulous connoisseur of flora and vegetation and very appreciated taxonomist, he contributed to the elaboration of the $12^{\text {th }}$ volume of the Flora R.S. România, describing in detail 10 Poaceae taxa [MITITELU, 1984]. In addition, he described, for the first time, new species (e.g. Asperula moldavica Dobrescu), hybrids and 20 infrataxa [IACOB, 2011].

Besides the Phytopathology course, Professor Dobrescu held the academic courses of Phytogeography and Botany for whose illustration used plants from the Botanical Garden. He 
Cătălin TĂNASE \& al.

published, in collaboration, impressive works as Păşunile şi fâneţele din România (The pastures and hayfields from Romania) in 1963. He was a member in the Subcommittee for Nature Protection and president of the Society of Biological Sciences - Iași Branch. He promoted the establishment of many natural reserves, including important plant areas for both species richness as well as rarity of the species perspectives. He was a valuable contributor to the Flora Romaniae Exsiccata (20 species) and Flora Moldaviae et Dobrogeae Exsiccata (34 species) [MITITELU, 1984].

Remarkable botanist and excellent teacher, ample and meticulously documented, dr. Emilian T,opa (1900-1987) was invited and agreed (advised also by dr. Alexandru Borza) to coordinate the organization of the Botanical Garden on its current place [MORARIU, 19781980], in whose service he put all his previously accumulated experience as director of the botanical gardens from Cluj-Napoca (1952-1960) and Chernivtsi (1944). Thus, in collaboration with other botanists and architects, he elaborated the plan of the Botanical Garden and the scientific themes of the sections. After transferring the plants from the Garden near the University, he initiated activities for the stabilization of the eroded slopes by planting tree and shrub species in the most affected places, and increased the area of the institution from 30 hectares to 65 hectares. Under his coordination (1963-1970), were built: the greenhouses complex $\left(7,100 \mathrm{~m}^{2}\right)$, the main entrance, the first alley system $(3,000 \mathrm{~m}$ in length) and also some irrigation systems [ŞTEFUREAC, 1979]. He also put the bases of the Herbarium, the museum and the library of the Botanical Garden.

In addition to coordinating the above mentioned institutions, dr. Emilian Ţopa carried out an impressive activity as curator at the Museum of the Botanical Garden in Cluj-Napoca and also an important didactic activity in various universities from Bucharest, Chernivtsi, and Iaşi [MITITELU \& LEOCOV, 1987]. His scientific contribution was focused on studies of plant taxonomy and ecology, phytosociology, ethnobotany and nature conservation. He was an expert in the most advanced research methods and analysis of vegetation, knowledge accumulated at Montpellier, under the guidance of dr. Josias Braun-Blanquet. He was the first author who investigated and described the halophilic vegetation in the country (e.g. Halophilic vegetation in northern Romania in connection with the halophilic vegetation in the rest of the country). The vegetation class of Puccinellio-Salicornietea Tुopa 1939 is still valid and widely recognized today. In his publications are highlighted 70 new species for Romania. He was one of the erudite who elaborated nine (of thirteen) volumes of the Flora R.S. România, by characterizing 207 species in 91 genera [MITITELU \& LEOCOV, 1987]. He collected and contributed to Flora Romaniae Exsiccata (Cluj) and Flora Moldaviae et Dobrogeae Exsiccata (Iaşi) with an enormous quantity of herbarium material. Dr. Emilian T,opa remains for eternity a symbol of erudition, the man who dedicated himself to science, education, organization and development of the Botanical Garden of Iaşi.

For establishing the plan and the general theme of the Botanical Garden from Copou Hill, Director Țopa collaborated with botanist Maria Lazăr for the Greenhouse Complex (who also coordinated the Herbarium between 1968 and 1977), botanist Elena Marin for the Ornamental Section (who also coordinated the Herbarium between 1977-1984), dr. Toader Chifu, for the Systematic Section, agronomist engineer Ioan Ostaciuc for the Rosarium Section, agronomist engineer Valeriu Movileanu for the Useful Plants Section, agronomist engineer dr. Ionel Lupu for the Dendrological section and dr. Corneliu Tăbăcaru for the Biological Section [MITITIUC \& TONIUC, 2006].

A close collaborator of Director Țopa was, during 1965-1968 the botanist (at that time) Professor dr. Toader Chifu (born in 1936), who organized the Systematic Section of the 
Botanical Garden according to the main phylogenetic systems. His great scientific and didactic career started as assistant professor at the Botany Department of the Faculty of Natural Sciences and Geography of the "Alexandru Ioan Cuza" University (1960-1965), continued at the Botanical Garden, at the Romanian Academy (Iaşi branch, 1968-1976) and as Head of the Collective for terrestrial ecology within the Center of Biological Research from Iaşi (19761980). Also he held Botany and Plant Ecology courses at the National Agronomical Institute from Alger (1976-1980). Returned in the country he connects the research and didactic activities, both at the Center of Biological Research and the Faculty of Biology. He is interested in mycology, mycocoenology, botany, nature conservation, and particularly phytosociology. The four volumes of Diversitatea fitosociologică a vegetaţiei României [The Phytosociological diversity of Romania's vegetation] synthesize his great experience in vegetation classification and describe over 1,200 syntaxa from Romanian vegetation. He is member in the scientific board of numerous scientific journals, of many scientific societies from Romania or abroad, and mentor for numerous PhD students [MARDARI \& TĂNASE, 2016].

One of his PhD students is dr. Constantin Mardari, who in 2003 became a biologist at the Botanical Garden of Iași and is presently coordinator of the Romanian Flora and Vegetation and Moldavian Silvosteppe sections. His researches focus on the ecology and chorology of certain plant species, on the syntaxonomy and structure analysis of several plant communities. He completed his $\mathrm{PhD}$ studies with the thesis Diversitatea floristică și fitocenologică a ecosistemelor naturale din bazinul Neagra Broștenilor (Floristic and phytocoenological diversity of natural ecosystems from Neagra Broștenilor basin), publicly defended in 2010. Dr. Mardari is also associated with the Faculty of Biology, involved in the specialized field practice for Biology and Ecology students. He also held the theoretical course and seminar for The methodology for preparing the environmental impact studies. As an active member of the Eurasian Dry Grassland Group, he is part of several international actions, with many relevant publications in the above mentioned scientific fields.

After a relatively short time as biologist (1998-2000) in the Romanian Flora and vegetation section of the Botanical Garden, dr. Ciprian Mânzu obtained, by contest, an academic position at the Faculty of Biology and currently he is Lecturer within the same institution. He published, in collaboration, reference books of plant taxonomy, floristics and phytosociology, such as Flora ilustrată a plantelor vasculare din Estul României (Illustrated flora of vascular plants from Eastern Romania) or Flora şi vegetaţia Moldovei (Flora and vegetation of Moldova) in two volumes (2006), as well as numerous scientific articles in prestigious journals, focusing on flora, biodiversity conservation, plant and vegetation ecology, Natura 2000 habitats, climate change, glacial and post-glacial relict plant species. Currently he holds several academic courses and laboratories: Plant systematics, Forest resources, Field methods in ecology, Habitats and species of Community Interest, etc.

Between 1973 and 1990 Professor dr. eng. Mandache Leocov (1928-2018), an expert in agriculture, landscape architecture, exotic and native ornamental species, etc., coordinated and continued to organize the Botanical Garden. Thus, by taking into administration the so called "Petrescu plot", donated by the family of the great botanist Constantin Petrescu, he opened the access (through a wood gate carved with plant motifs, creation of Professor Dumitru Zaucă) in the Garden directly from the Exhibition Park [TĂNASE \& OPREA, 2018]. He inaugurated the Palmarium greenhouse (1974) and organized the Didactic-Experimental section. Together with his colleagues, he put the bases of the Rosarium section, inaugurated it in 1979, started (in 1976) to organize the main exhibitions of the Botanical Garden (one displaying azaleas and camellias as floral arrangements in the hall of the administrative building, 
and another presenting the chrysanthemums and bonsai collections) and continued to consolidate some problematic areas affected by landslides.

He continued the work of his predecessors to Flora Moldaviae et Dobrogae Exsiccata. Together with the architect V. Carmazin-Cacovschi he created the first model of the institution, highlighting each section. In his didactic activity he went through all the academic stages until full professor. He held the Dendrology, Agriculture, Agro-phyto-technology courses [MITITELU \& COSTICĂ, 1993] in various academic institutions from Iasi. Besides the Botanical Garden, Professor Leocov organized many green spaces in Iaşi and was preoccupied by the protection of some monumental trees in the city (as Eminescu's linden). He edited the first editions of the Guide of the Botanical Garden from Iaşi volume (1985 and 1989), presenting the history of this institution and the personalities who was involve in its establishment and organized the national symposia dedicated to the anniversaries of the Botanical Garden in 1976, 1981, and 1986 [MITITELU \& COSTICĂ, 1993]. He is remembered as the Professor who always presented Iaşi as a city of flowers and parks [TĂNASE \& OPREA, 2018].

An important role in the development of the Botanical Garden had engineer dr. Ionel Lupu, coordinator of Dendrarium section between 1967 and 1998. He was directly involved in the elaboration of this section's general plan, in the organization and diversification of the woody plants collections, introducing and acclimatizing many indigenous and exotic species. He perfected his studies by defending, in 1980 his $\mathrm{PhD}$ thesis at the Agronomic Institute of Iași - Flora și vegetația pădurilor dintre Siret, Moldova și Șomuzul Mare (The flora and vegetation of forests between Siret, Moldova and Șomuzul Mare), under the supervision of professor dr. Mihai Răvăruț. Member of many associations dedicated to the conservation of woody species, he initiated several civil projects for the inventory, monitoring and protection of trees across the city of Iași, as well as trees plantations activities, implicating people from different social classes, pupils and students, children and adults, raising awareness towards the importance of forests preservation.

Another great name, who brought value to both the Botanical Garden and the Faculty of Biology, was Professor dr. Dumitru Mititelu (1929-2005). He was a member of the Scientific Committee of the Botanical Garden (1967-1975) and in 1988 was named honorary director of this institution. He graduated the Faculties of Natural Sciences, Philosophy and Agronomy, all from Iași and defended his $\mathrm{PhD}$ thesis - Flora and vegetation of the Elan basin and hills in 1973, under the supervision of Constantin Burduja [OPREA, 2019]. He started his career at the Agronomic Institute of Iaşi and after he transferred to the Faculty of Biology, where he held the Plant systematics, General biology, Romanian phytocoenology and vegetation courses. He also got to taught Tropical systematics and sinecology at the University of Kisangani (Republic of Zair, Africa).

With his studies focused especially the flora and vegetation of Moldova, he brought a new and modern approach to plant systematics, vegetation mapping and phytocoenology researches. He extensively published his investigations in more than 200 papers, as a single author or in collaboration with other specialists, revealing important data regarding, among many other aspects, over 800 rare species, from which 12 species were new for Romania, and 80 new for Moldova, 28 new for science plant communities and 2 subassociations, contributing at the Flora Romaniae exsiccata, Flora Moldaviae et Dobrogae exsiccata and Flora districti Bacoviensis exsiccata, with more than 80,000 Herbarium sheets [BARABAS,, 1980-1993]. Professor dr. Mititelu's dedication and professionalism impressed many generations and made him a mentor for tens of students, from which several followed a teaching or research career. 
After eight years at the Department of Botany of the Faculty of Biology, Senior Researcher dr. Ion Sârbu (born in 1933), joined the team of specialists from the Botanical Garden of Iași. He is a great personality of the Romanian Botany, a man passionate about the study of plants, perfectionist, full of patience and modesty, and of great moral integrity [TOMA, 2013]. For approximately 30 years (since 1975) he was the coordinator of the Romanian Flora and Vegetation section, and, for many years he served as Scientific Secretary of the Botanical Garden.

His prodigious research activity started in 1967 as curator of the Herbarium of the Faculty of Biology, and consists in numerous articles, books, and research projects, in fields of plant taxonomy, phytosociology, and nature conservation, activity for which he was granted many awards. He was actively involved in the development and implementation of the protected areas network "Natura 2000" in Romania. Reference books such as Plante vasculare din România. Determinator ilustrat de teren [Vascular Plants of Romania. Illustrated Field Guide] published in 2013 in collaboration with dr. Adrian Oprea and Professor dr. Nicolae Ștefan, synthesize his vast experience and is highly appreciated by both specialists, and people who are interested in discovering the Romanian flora. He is a valuable contributor to Atlas Florae Europaeae and Euro+Med PlantBase. He is also valued by many generations of biology students (but also students from the Environmental Engineering department of the Technical University) to whom he held academic courses and laboratories referring to forest resources, biodiversity of terrestrial and aquatic environments, botany, biogeography, etc. [OPREA, 2013].

Dr. Adrian Oprea, presently coordinator of the Systematic section, completed his studies under the supervision of professor dr. Mititelu, defending his PhD thesis entitled Flora și vegetaţia din Câmpia Tecuciului și Bazinul Inferior al Siretului (Jud. Galați) [Flora and vegetation from Tecuci plain and Inferior Basin of Siret river (Galați County)] in 1998, at the Faculty of Biology, "Alexandru Ioan Cuza" University of Iași. Besides his involvement in the development and maintaining the natural patrimony of the section, he actively contributes to the better knowing of the flora and vegetation of certain regions of Romania, including natural protected areas, the identification and distribution of several vascular plants, proposal of new plant communities and sub-communities (for science or for Romania), restoring plant communities on tailings. He is member of the Romanian Phytosociology Society and the International Dendrology Society, associated with the Faulty of Biology, where he held the practical works and specialized field practice for the Phytosociology course, actively collaborating in his researches with academic personnel from many Universities from Romania and abroad.

\section{Plant morphology and anatomy}

Studies focused on the anatomic structure of plant species and also on histology, and plant physiology were published stating with the second half of the nineteenth century [IACOB, 2011] by great scientists who also had close relationships with the Botanical Garden of Iași. The first contributions in these scientific fields were published by Dimitrie Brândză (1867) and Alexandru Popovici (1893) and mainly represents the results of their doctoral theses. The first university manual of plant histology, organography, and plant physiology was elaborated by Anastasie Fătu (1877). Also, Constantin Papp carried out studies on the structure of the leaves of some medicinal plants (1942). Until 1948 the discipline of plant morphology was taught within the more broadly course of Botany. The botanist and phytosociologist, director of the Botanical Garden, Professor Constantin Burduja held the Plant Morphology course until 1971 (he is the founder of the first school of plant morphology and anatomy in Romania), and, since 
then, for almost forty years, this academic course (besides plant cytology, plant embryology, evolutionary strategies in plant realm, and others) was held by Academician Constantin Toma (1935-2020).

Professor dr. Toma was also appointed Director of the Botanical Garden between 1970 and 1973, where he continued the organization of the garden's sections, enrichment of plant collections, the establishment of microhabitats with characteristic plant species, organization of scientific expeditions in order to collect plants, fruits and seeds from species in different regions of the country, and initiated fruitful collaborations with similar institutions from Romania and abroad.

Professor dr. Toma initiated the design and construction of the Palmarium greenhouse and edited two centurias of Flora Moldaviae et Dobrogea Exsiccata. He promoted the use of the Garden in teaching and education activities and had the initiative to organize and develop a laboratory of plant morphology and plant anatomy in this institution where he started the first studies on medicinal and ornamental species as well as studies of experimental and ecological anatomy [MITITIUC \& TONIUC, 2006]. He was passionate about the history of the Botanical Garden and by the personalities who contributed to its foundation and development, and published appreciative articles about Anastasie Fătu, Dimitrie Brândză, Constantin Papp, Constantin Burduja and Constantin Dobrescu [TONIUC, 2010]. He continued to be present in the Botanical Garden all his life, and had unforgettable interventions especially on the occasion of flower exhibitions.

His exceptional didactic career extends on over sixty years, period when he developed at the Faculty of Biology of the "Alexandru Ioan Cuza" University the most valuable school of plant morpho-anatomy in the country [IVĂNESCU \& ZAMFIRACHE, 2010], widely recognized. He was a Professor with great vocation, highly appreciated for his memorable academic lectures, coordinator for 28 doctoral theses. In his prolific scientific career he published over 500 scientific articles and reference books, as well as other hundreds of articles of popularization, on the history of biology, book reviews, etc. [IVĂNESCU \& al. 2020] for which he was granted many distinctions and awards. His extensive and valuable contributions to the development of numerous research directions in the field of plant biology recommended him to become a member (1991) of the Romanian Academy in the Department of Biological Sciences, and honorary member of the Academy of Sciences of the Republic of Moldova (2011). He was the scientific secretary of the Romanian Academy - Iaşi Branch and president of the Sub-commission of Nature Monuments of Moldova within the same institution.

Besides the position of the director of the Botanical Garden, he was vice dean and dean of the Faculty of Biology, scientific secretary in the Senate of "Alexandru Ioan Cuza" University, director of the Institute of Biological Research from Iași, vice-president and honorary president of the National Society of Biological Sciences (since 2007), member of the National Council for Academic Evaluation and Accreditation (1994-2005), member of the Biology Commission of the National Council for Attestation of University Degrees, Diplomas and Certificates (1994-2005), member in the Council of the Romanian Academy Publishing House (1996-2003) [IVĂNESCU \& al. 2020].

He was a Professor distinguished by the elegance of expression, precision and clarity of the language, emblematic by the attitude and scientific authority in the department, in the laboratory and in the field, respected, by collaborators, who shaped the professional destinies of most of the disciples who continues his activity [MITITELU, 1993; IVĂNESCU \& ZAMFIRACHE, 2010], both at the Faculty of Biology and the Botanical Garden. 
At the Botanical Garden he was surrounded by an enthusiastic team of young botanists and engineers, deeply involved both in their professional development and the development of the botanical garden. One of his collaborators, was botanist dr. Corneliu Tăbăcaru, coordinator of the Biological section between 1967-2004. He contributed to the elaboration of the organizational plan and the theme of this section, he was implicated in the introduction of new species within the existing collections, dedicating his time to research in the fields of plant morphology and embryogenesis. He graduated the Faculty of Biology, "Alexandru Ioan Cuza" University of Iași, further specialized at the University of Bucharest and in 1984, under the coordination of Traian Ștefureac defended his $\mathrm{PhD}$ thesis entitled Cercetări de morfologie ale mugurilor, embriogeneză și fenologie la nuc și vișin cu unele considerații taxonomice și importanța lor în pomicultură (Researches about buds morphology, embryogenesis and phenology in walnut and sour cherry with taxonomical considerations and their importance in tree culture). Even after his transfer to the Botanical Garden of Iași, he continued the collaboration with the academic personnel from the University of Bucharest, carrying on studies and researches in the above mentioned fields.

Under the supervision and coordination of Academician Constantin Toma, many biologists from "Anastasie Fătu" Botanical Garden completed their studies and became specialists in their field.

An illustrious representative of the Plant Morphology and Anatomy School from Iași, and a remarkable researcher for over 30 years at the Botanical Garden was dr. Rodica Rugină (1940-2021). She coordinated the Systematic Section, and increased the dimensions of plant collections, with a special preoccupation for rare and threatened plant species and their ex situ conservation. She closely supervised the introduction and acclimatization of some protected plant species in the Botanical Garden while tried to increase the interest of visitors by creating an open-air amphitheater, a basin with aquatic plants and some fountains [ADUMITRESEI \& IFRIM, 2020]. Before transferring to the Botanical Garden, dr. Rugină started her academic career in 1963 as assistant professor at the Faculty of Pharmacy and Faculty of Biology, in the field of plant morphology [TOMA, 2015]. She continued to collaborate with the specialists of the Plant Biology Department in studies focused on comparative, ecological and experimental plant anatomy. Reference books as Plante ocrotite din România (Protected plant species from Romania) and Anatomia plantelor medicinale (Anatomy of medicinal plants) highlights her main scientific preoccupations.

With a career of over 35 years, dr. Angela Toniuc coordinated the World Flora section (currently the Phytogeographic section) of the Botanical Garden. From the very beginning she was involved in the elaboration of the scientific theme of the section and the establishment of the plantation, followed by the care and enrichment of the plant collections. She put the bases of the bonsai collection, which now includes hundreds of specimens, and is probably the most valuable in the country. She also was responsible for the international seed exchange (19852001) and publication of the Delectus Seminum et Sporarum catalogue, distributed to hundreds of similar institutions from all continents. The valuable experience dr. Angela Toniuc determined her appointment as member in the scientific council of the Botanical Garden of Iaşi (and also of Galați Botanical Garden since 1990). The didactic activity, carried out between 1990 and 2000, as associated professor at the Faculty of Biology, was focused on disciplines as Plant anatomy, Plant embryology and Ecological biogeography [TOMA, 2014; IFRIM \& ADUMITRESEI, 2019].

The scientific activity of dr. Angela Toniuc is related to plants morphology and anatomy, plants embryology, as well as plant taxonomy, floriculture and history of botany 
[TOMA, 2014]. She published as single author or in collaboration, over 130 articles and books, including reference books as: the four volumes of Flora lemnoasă spontană şi cultivată din România (The ligneous flora native and cultivated in Romania] in collaboration with dr. Ion Sârbu, and professor Valeriu Zanoschi, or Adaptarea la mediu în lumea plantelor [Adaptation to the environment in the plant world). In Grădina Botanică Anastasie Fătu. File de istorie (Anastasie Fătu Botanical Garden. History sheets), together with Professor Mihai Mititiuc, she documented and presented the efforts of all who contributed, in time, to the foundation and development of this institution. All her collaborators appreciate that dr. Angela Toniuc is an example of seriousness, tenacity, erudition, and altruism.

Dr. Georgeta Teodorescu was the coordinator of the Central and South America subsections of the World Flora section (1970-1994) and the Greenhouse Complex (1988-2004), actively participating in the development of these sections, diversifying the plant collections and promoting them. She obtained her $\mathrm{PhD}$ title in 1998 with the thesis entitled Cercetări privind morfologia și structura unor plante in condiții de parazitare (Researches regarding the morphology and structure of some plants in parasitic conditions), under the supervision of Professor dr. Toma. Her major scientific interest included the morphological and histological study of angiosperms plantlets, structural modification induced by phytopathogenic fungi, the horticultural value of several plant collections, publishing various articles in collaboration with her mentor, Professor dr. Toma, or with colleagues from the Botanical Garden and the Faculty of Biology.

In 1994-2012, dr. Violeta Tănăsescu carried out scientific activities in numerous sections of the Botanical garden: she coordinated and elaborated the scientific thematic of the Memorial plants section (1994-2003), contributed to the enrichment of plant collection from Ornamental section (2000-2001) and the Useful Plants section (1997-2005), and coordinated the Greenhouses Complex (2005-2012). Her research activity was focused on the morphology and anatomy of medicinal, ornamental or rare and threatened plant species. Under the supervision of Academician Constantin Toma, she elaborated the $\mathrm{PhD}$ thesis - Cercetări de morfo-biometrie și histo-anatomie ontogenetică comparată și experimentală la diferite specii şi soiuri de pomi fructiferi din familia Rosaceae (Researches of morpho-biometry and ontogenetic, comparative and experimental histo-anatomy of various species and varieties of fruit trees in Rosaceae family). She was also preoccupied of the guidance in botanical gardens, especially of aspects for the improvement of the communication process to the persons with special needs, and of the modalities to use the botanical garden's patrimony in order to maximize the benefits for the same category of people.

Dr. Camelia Ifrim, coordinator of the World Flora section between 2001 and 2009 and currently of the Greenhouse Complex, is a disciple of Professor dr. Toma, under whose supervision, in 2005, obtained her $\mathrm{PhD}$ title with the thesis - Cercetări morfo-anatomice și fiziologice asupra organelor vegetative de la unele plante decorative ierbacee (Morphoanatomical and physiological researches of vegetative organs from some herbaceous decorative plants). Her domains of interest include morphological, histological and anatomical aspects of plant species with different bio-geographical origin, plant physiology, embryogenesis, seed dormancy and mechanisms to break it. As coordinator of the Greenhouse Complex she carries out specific activities such as: identification of exotic taxa, organizing and maintaining the plant collections and developing ways to present them to the public, involvement in the educational and cultural events organized by the Botanical Garden.

Although for a relatively short time in the Botanical Garden (2008-2010), dr. Irina Elena Stănescu brought an important contribution to the development of the institution 
especially of the collections of the Useful Plants section (as coordinator), the international seed exchange and publication of the catalogue Delectus Seminum et Sporarum. Her scientific activity was focused on plants morphology and anatomy as well as plant taxonomy, particularly on carnivorous plant species, the subject of her doctoral thesis, Cercetări citologice și histoanatomice asupra unor specii de plante carnivore (Cytological and histo-anatomical research on certain carnivorous plant species) coordinated by Academician Constantin Toma.

Dr. Lidia Adumitresei, presently coordinator of the Biological section completed her professional training with the doctoral studies under the supervision of Professor dr. Toma, defending her PhD thesis entitled Cercetări morfo-anatomice și fiziologice asupra unor specii şi soiuri de Rosa L. (Morpho-anatomical and physiological researches of several species and varieties of Rosa L.), in 2011, at the Faculty of Biology, "Alexandru Ioan Cuza" University of Iași. She is actively participating at the development and conservation of the natural patrimony of the Biological section, but also involved in research activities regarding the nomenclature and origin, stem and leaf morphology and anatomy of several rose species and varieties adapted to local conditions, the content of carbohydrates, assimilatory and anthocyanin pigments, volatile oils and enzymes involved in the respiratory process from several taxa belonging to Rosa genus. She is a member in various national and international societies and associations, such as: Amicii Rozelor Association from Romania, and International Hibiscus Society.

\section{Mycology and phytopathology}

The scientific activity in fields of phytopathology and mycology at the Faculty of Natural Sciences from Iaşi starts in the early twentieth century and is coordinated by Professor Alexandru Popovici, who, besides Botany, was preoccupied by diversification and development of new scientific domains. Detached from the discipline of Botany, the Phytopathology academic course was held by also by Professor Constantin Dobrescu and continued, for almost five decades by Professor dr. Mihai Mititiuc, while nowadays it is held by Professor dr. Cătălin Tănase (in this article were highlighted only the academic personalities who coordinated or worked in the Botanical Garden).

With a great managerial capacity, tenacity, and perseverance, Professor dr. Mihai Mititiuc (1937-2020) coordinated activities in the Botanical Garden during 1990-2007, in a period characterized by many social and economic problems. During this time, together with his colleagues, he managed to repair and modernize the greenhouses complex, and to inaugurate three new ones while preparing the project for a new aquarium greenhouse, founded the subsection for people with visual disabilities within the Ornamental section and supported the organization of annual flower exhibitions. He contributed to enrichment of plant collections and ex situ conservation of rare or endangered species by promoting national and international exchange of plant seeds and by organizing field expeditions in various regions of the country. In this direction, he was preoccupied to establish an alpine Botanical Garden at the Potoci research station. He edited the last two centurias of Flora Moldaviae et Dobrogae Exsiccata.

Concerned with honoring the memory and achievements of the predecessors, Professor Mititiuc ordered the installation of bronze busts that evoke great personalities involved in the development of the Botanical Garden, and organized scientific symposia with the occasions of celebrating the $140^{\text {th }}, 145^{\text {th }}$, and $150^{\text {th }}$ anniversary of the Botanical Garden. He edited the third edition of Guide of the Botanical Garden and reorganized the journal of the institution Buletinul Grădinii Botanice Iaşi (Bulletin on the Botanical Garden from Iaşi). He was also involved in organizing 12 editions of the National Symposium of Mycology (1995-2007) as 
well as Second National Congress of Biology (1992). He was the president of the Mycological Society of Romania and of the Association of Botanical Gardens from Romania.

The didactic activity of Professor dr. Mititiuc was mainly carried out in the fields of Phytopathology and Mycology, disciplines for which he organized the Laboratory of Mycology and Phytopathology within the Faculty of Biology (1993). He also held the academic course of Biogeography, and in the early stages of his career, laboratories of Plant morphology and anatomy, Biology of plant pathogens, Plants Protection, etc. As PhD coordinator, he contributed to the formation of many young specialists in the field of mycology and phytopathology [TĂNASE \& al. 2020]. He had a prolific scientific activity, materialized in identification and publication of numerous micromycetes species, new for science, of their taxonomy, ecology and biology. Moreover he studied and published the micromycete species identified in the Botanical Garden [MITITIUC, 1973; MITITIUC, 1979; MITITIUC 1982; MITIUC 1984a; MITIUC 1984b; MITITIUC 1985; MITITIUC, 1986a; MITITIUC, 1986b; MITITIUC, 1987a; MITITIUC, 1987b; MITITIUC, 1989; MITITIUC, 1991; MITITIUC, 1992a; MITITIUC, 1992b; MITITIUC, 1993]. His PhD thesis, coordinated by Professor dr. Olga Săvulescu, was focused on fungal diversity from important natural reserves - Contribuţii la cunoaşterea micromicetelor şi macromicetelor din rezervaţiile naturale Ponoare şi Frumoasa - Suceava (Contributions to the knowledge of micromycetes and macromycetes from the nature reserves Ponoare and Frumoasa - Suceava). He also published reference books in the fields of phytopathology [TĂNASE, 2012], such as Biologia paraziţilor vegetali (1980) (Biology of plants parasites), Ciuperci parazite pe arborii şi arbuştii din pădurile noastre (1997) (Parasitic fungi on the trees and shrubs from Romanian forests) or Bolile şi dăunatorii plantelor medicinale şi aromatice (2000) (Diseases and pests of medicinal and aromatic plants). He also had the initiative to organize the scientific communication sessions of the Faculty of Biology in close collaboration with the specialists from the Botanical Garden. He remains a symbol of tenacity, continuous effort and devotion to scientific knowledge and to the Botanical Garden.

He had an important contribution to the scientific perfecting of the employees from the Garden, by sending them in training stages at other institutions in the country or abroad and many of his students continued their professional development by enrolling at the doctoral school from the Faculty of Biology.

One of his students, dr. Profira Vidrașcu, was coordinator of the Ornamental Section - Chrysanthemum collection, closely involved in the diversification of the chrysanthemum collection, culture methods and phytopathology, developing new varieties with decorative value. Over the years, she published articles and books covering many aspects regarding the culture technology for chrysanthemums and completed her university studies with the $\mathrm{PhD}$ thesis entitled Cercetări asupra taxonomiei, fitopatologiei şi bazele ecofiziologice ale tehnologiei de cultură a unor specii și soiuri de crizanteme din colecția Grădinii Botanice din Iași [Researches regarding the taxonomy, phytopathology and ecophysiological basis of the culture technology for several species and varieties of chrysanthemums from the collection of the Botanical Garden of Iași], which she publicly defended in 1995, at the Faculty of Biology.

Between 2001-2004 botanist dr. Cristina Pricop-Ciocoiu coordinated activities in the Ornamental section of the Botanical Garden. Besides decorative plant species, her research activity was also focused on the parasitic micromycetes on cultivated tree species in parks and gardens, within Uredinales and Erysiphales taxonomical orders. For the thesis entitled Ciuperci parazite pe plante lemnoase ornamentale din spațiile verzi urbane ale Moldovei (Parasitic fungi on ornamental woody plants in the urban green spaces of Moldova), coordinated by Professor Mititiuc, she was granted a PhD diploma in the field of Mycology. 
Another student of Professor dr. Mititiuc, dr. Vasilică Claudiu Chinan coordinated the current maintenance activities in the Romanian Flora and vegetation section of the Botanical Garden (2002-2004) and carried out mycological research activities. Currently, he is Lecturer at the Faculty of Biology, where he teaches the Plant taxonomy courses and laboratories for Mycology and Phytopathology. He published, in collaboration, reference books in fields of fungi taxonomy - Macomicete din Romania (Macromycetes from Romania), and fungi diversity Parcul National Călimani. Studii ecologice şi de biodiversitate, Mycobiota (Călimani National Park. Ecological and biodiversity studies. Mycobiota), as well as numerous scientific articles in prestigious journals from the country and abroad, highlighting new fungal species for Romania which he discovered.

Dr. Ana Cojocariu was the coordinator of the Useful Plants section (2005-2008; 2010-2015) and currently coordinates the activity within the Ornamental section - the Chrysanthemum collection. She specialized in mycology, in 2007 defending her $\mathrm{PhD}$ thesis entitled Macromicete implicate în degradarea lemnului din construcții la monumentele istorice din Moldova (Macromycetes involved in the degradation of construction wood from historical monuments in Moldova), having as main interests macromycetes taxonomy and ecology, fungal mechanisms of wood degradation, fungal succession and participating, as a member of the Romanian Mycological Society and the European Mycological Association, at scientific and popularization activities regarding fungi and their importance in natural and anthropic environments. She was also involved in the teaching activities at the Faculty of Biology, by holding the laboratory works for the Phytopathology and Biology of vegetal parasites courses. The nature of the specific activities carried out within the section she coordinates gave her the opportunity to maintain and diversify a unique plant collection, to improve the culture methods, and to develop, from the existing taxa, new varieties of chrysanthemums, very well adapted to the local conditions, resistant to pathogens and with special decorative value.

After the short period (2003-2004) in which the biologist Constantin Ciocoiu coordinated the activities in the Dendrarium section, since 2005 Dr. Ciprian Bîrsan took over these tasks and is involved in the conservation and preservation of the natural patrimony of the Botanical Garden, in the development of the living plants and fungi collections, participating at botanical expeditions in different regions of Romania and gathering material (seeds, cuttings, fruiting bodies) for research or educational purposes. He completed his studies with the $\mathrm{PhD}$, which he defended in 2008 with the thesis Diversitatea taxonomică şi ecologică $a$ macromicetelor din masivul Giumalău (Carpații Orientali) (Taxonomical and ecological diversity of macromycetes from the Giumalău Massif(Eastern Carpathians)) at the Faculty of Biology. His main domains of interest include the taxonomy, ecology and chorology of macromycetes, monitoring natural habitats and ecosystems. He is also associated with the Faculty of Biology, where he held the laboratory works for the Mycology course and collaborating with academic personnel in elaborating studies, books and articles in the related fields. He is a member of the Romanian Mycological Society, being involved in organizing and implementing scientific and educational activities.

In March, 2007, after the results validation of the contest for the position of manager, Professor dr. Cătălin Tănase was appointed Director of the Botanical Garden by the University's management. From the very beginning he was preoccupied to promote the Garden as an institution of education and culture, and to modernize the existing infrastructure. Professor Tănase was decisively involved in the foundation of the Laboratory for micro-propagation and preservation of germplasm, improving the conditions for seed conservation, and establishing the Research Group for Micro-propagation and Preservation of Germplasm 
(GERMOBIOTECH). Under his management, almost all compartments of the greenhouses were rehabilitated: the exhibition greenhouse, the multiplier greenhouse, the greenhouse for the indoor culture of chrysanthemums, as well as the spaces for storing and conditioning the biological material, and for garden's staff. Together with the Rector of the University, Professor Vasile Ișan, he inaugurated the new greenhouses, with an area of $1.100 \mathrm{~m}^{2}$ (2013). He reorganized the Ornamental section, and reopened after 17 years, the garden's main entrance. Also, through various projects that Professor dr. Tănase coordinated, in the Systematic Section, the Auditorium for educational and cultural activities was completed, and a new pool harboring species and varieties of water lilies and other aquatic species was inaugurated (2016), the Useful Plants section was reorganized (2018) and a new subsection including plant species named to honor the great scientific personalities was presented to the public, the lighting system on the main alleys was modernized and a photovoltaic system was introduced the Rosarium section. He also modernized the Herbarium, while in the Biological section was started (2019) the organization of a Japanese garden.

Professor Tănase continues today the work of his predecessors, coordinating the specific activities of enrichment the living plant collections, organizing the traditional events: the Autumn Flowers (the Chrysanthemum collection increased during his mandate to 450 varieties, including new created varieties; he also started and increased the collections of decorative cabbage - 76 taxa, chilies - over 130 taxa, and decorative pumpkins - over 200 taxa), the Exotic Plants exhibitions, editing the journal of the Botanical Garden (named since 2007 Journal of Plant Development) and the Catalogue with the seed offer for exchange, promoting the institution's achievements and honoring all the predecessor who contributed to the establishment and development of the Garden. Also, honoring the memory of his predecessors, he installed the bust of Professor dr. Mandache Leocov in the Administrative building, a work of art realized by sculptor Constantin Crengăniş and donated by Professor Emil Gentimir. The exhibitions of fresh edible and toxic mushrooms represents a novelty element. Under his coordination the institution was accepted as member in the International Network for Plant Exchanges (2009) and of the Association of Botanical Gardens of Coimbra Group Universities (2011).

The academic career of Professor Tănase is focused on the fields of Mycology and Phytopathology, and since 2009, he coordinates doctoral theses in the field of Biology. His research activity focuses on taxonomy and ecology of fungi, conservation of fungal diversity, and the biocontrol and bioremediation of pollutants. His scientific activity is widely recognized and, as a consequence, he was granted many awards. For the thesis Cercetări sistematice şi ecologice asupra micromicetelor din Masivul Rarău (Systematic and ecological researches on the micromycete species from Rarău Massif) he received a PhD diploma in Botany domain. He authored numerous reference books, among which Macromicete din România (Macromycete species from Romania), Concepte actuale în taxonomia ciupercilor (Current concepts in fungi taxonomy) or Fungi cu aplicaţii în agricultură, medicină şi patrimoniu (Fungi with applications in agriculture, medicine and heritage) are highly valued by specialists. Due to his remarkable scientific contributions, in 2018 was elected corresponding member of the Romanian Academy. $\mathrm{He}$ is also member of prestigious scientific organizations as the Romanian Mycological Society (president since 2014); Association of the Botanical Gardens in Romania (vice president 20082016; president 2016-2018) or in the council of the European Mycology Association (since 2007). He organized a significant number of scientific events, among which, the $155^{\text {th }}, 160^{\text {th }}$ and $165^{\text {th }}$ anniversaries of the institution $(2011,2016$, and 2021) which were attended by many specialists from all botanical gardens in Romania and from many similar foreign institutions. 
By creating the slogan "Science and culture for nature", Professor dr. Tănase defines the purpose of the "Anastasie Fătu" Botanical Garden, and reinforces its mission as an institution dedicated to ex situ conservation of plant species, education, recreation, and promotion of the cultural values.

A valuable and close collaborator of Professor dr. Tănase is dr. Tiberius Balaeş, who worked for five years (2013-2018) as a researcher in the Botanical Garden, in fields such as taxonomy and ecology of fungi, bioremediation of certain categories of pollutants, isolation in pure culture and selection of fungi, optimization of culture conditions, cryopreservation of fungal mycelium, etc. In 2013 he defended his $\mathrm{PhD}$ thesis entitled Izolarea și selecția unor specii de macromicete cu rol în biodegradarea coloranților sintetici (Isolation and selection of some species of macromycetes involved in the biodegradation of synthetic dyes). The results of his researches were published in prestigious national and international journals. His didactic talent and qualities, recommended him for an academic career and currently is head of works at the Faculty of Biology, "Alexandru Ioan Cuza" University from Iaşi, where he teaches courses and laboratories, both for the bachelor and master programs, for several disciplines such as: Microbial bioconversions, Cryptogams systematics, Medical mycology, Strategies in biodiversity conservation, Principles of eco-tourism, etc. and is responsible for the specialized filed practice for the Faculty's students.

Dr. Cristiana Virginia Petre, presently coordinator of the Useful Plants section, is involved in maintaining and diversifying the useful plants collections and is responsible with the educational activities organized within the Botanical Garden, alone or in partnership with different institutions: schools, universities, NGOs, being part in many biodiversity conservation actions as an active member of the Romanian Mycological Society and Romanian Ornithological Society. In 2018 she participated at the specific actions for reorganizing the Useful Plant section, information gathering and ways to present it to the public. Alongside with this activity, her domains of interest include fungal taxonomy and ecology, in vitro isolation of fungal species, biotechnological potential of fungi. She obtained the $\mathrm{PhD}$ title in 2016 with the thesis entitled Studiul unor specii de basidiomicete lignicole cu rol în sinteza compuşilor organici volatili (The study of some lignicolous basidiomycetes species involved in the synthesis of volatile organic compounds). She currently holds the laboratory works for the Cryptogams Systematics course at the Faculty of Biology.

For approximately 10 years, dr. Ovidiu Copoț carried out various research activities in the Dendrarium section of the Botanical Garden. His scientific researches were mainly focused on using the statistical methods for the analysis on diversity of macromycete species. For the thesis Modelarea ecologică și spațială a unor specii de de macromicete în ecosisteme forestiere din Regiunea de Nord-Est (România) - Ecological and spatial modeling of some macromycete species in forest ecosystems of the North-East Region (Romania) he was granted a $\mathrm{PhD}$ diploma. In his research activity he is focused on identifying the relevant abiotic and biotic factors influencing the richness of fungi species, the composition of fungal communities, and on statistical modelling of their potential spatial distribution.

The current team of the Botanical Garden express their admiration for the dedication, passion and competence of their great predecessors and tries to rise to the height of their achievements. Although there was a change between generations, caused by the retirement of some great specialists, the relatively young, but enthusiastic team of biologists and engineers continued the researches, the organization of the traditional events and, when needed, the didactic activities, collaborating every year with academic personnel from "Alexandru Ioan Cuza" University of Iași, "Ion Ionescu de la Brad" University of Life Sciences from Iași or 
"Gigore T. Popa" University of Medicine and Pharmacy, in organizing the specialized field practice for the students. Today, that team includes 7 biologists: dr. Lidia Adumitresei, dr. Ciprian Bîrsan, dr. Ana Cojocariu, dr. Camelia Ifrim, dr. Constantin Mardari, dr. Adrian Oprea, dr. Cristiana Virginia Petre and 3 engineers: Iuliana Gaţu (Phytogeographic section), Mihaela Mihalache (Rosarium section) and Mihaela Popa (Ornamental section).

\section{Conclusions}

"Anastasie Fătu” Botanical Garden of Iași represents an important scientific, educational and cultural pole in Romania, the efforts of the founder, previous and present generations making it a valuable patrimony element. The dedication of people who participated at the establishment of this institution, their will and perseverance in overcoming every obstacle and their determination in offering the academic community, as well as the general public the opportunity to research and discover the world of plants are truly worth cherishing and celebrating.

The idea of organizing a botanical garden wasn't just a simple job requirement, but a soul driven mission, serving a greater purpose, that 165 years later still prevails. The 3 main objectives of any botanical garden: ex situ conservation of plant species, scientific research and educating people in the spirit of nature, were drawn since the beginning of this initiative, and permanently performed and improved.

The nature of the activity carried out at the Botanical Garden of Iaşi and the diverse and complex plant collections, offer vast opportunities for quality research within this institution, but also the opportunity of the employees to collaborate with academic personnel from the field of natural sciences: biology, agronomy, horticulture, pharmacy. In this way, the research of the biologists from the botanical garden alone or in collaboration cover various domains, starting with plant and fungal taxonomy, plant morphology, anatomy, physiology, embryology, biochemistry, phytocoenology, plant and fungal ecology and mapping, phytopathology, use of fungi in biotechnologies.

With every generation the value of "Anastasie Fătu" Botanical Garden of Iași increases, the fields of research expand, the species preservation techniques on medium and long term change with the development of technology, the culture methods improve, the plant collections diversify, and the manner of presenting them to the public shifts from the traditional approach to a more modern one, in order to meet both the plants requirements and the people's expectations.

\section{References}

ADUMITRESEI L. \& IFRIM C. 2020. Aniversalia. The $80^{\text {th }}$ Anniversary of the Biologist Rodica Rugină. Journal of Plant Development. 27: 195-197.

AIFTINCĂ M. 2014. Timp şi valoare. Studii de istorie a culturii şi filosofiei româneşti. Colecţia Opera Omnia, Cartea de Filozofie. Iaşi: Edit. Tipo Moldova, 239 pp.

BARABAȘ N. 1980-1993. Aniversări - Prof. dr. D. Mititelu. Studii și comunicări, Complexul Muzeal de Științele Naturii "Ion Borcea” Bacău. 13(2): 363-381.

BRÂNDZĂ D. 1883. Prodromul florei române sau enumeraţiunea plantelor până astăzi cunoscute în Moldova şi Valachia. Bucureşti: Tipografia Acad. Rom., 568 pp.

BURDUJA C. 1979. Profesorul Alexandu Popovici. Culegere de Studii şi Articole de Biologie. 1: 37-44.

BURDULA C. \& MIHAI G. 1976-1977. Botanistul Constantin Petrescu. Viața și opera. Studii și comunicări, Complexul Muzeal de Științele Naturii “Ion Borcea” Bacău. 9(2): 489-496. 
IACOB G. (ed.). 2011. Universitatea din Iaşi (1860-2010). Facultăţi. Profesori. Şcoli Ştiinţifice. Iaşi: Edit. Universităţii "Alexandru Ioan Cuza", 728 pp.

IFRIM C. \& ADUMITRESEI L. 2019. The $75^{\text {th }}$ anniversary of the biologist Angela Toniuc. Journal of Plant Development. 25: 201-203.

IVĂNESCU L. \& ZAMFIRACHE M. M. 2010. In Honorem. Profesorului Constantin Toma la a 75-a aniversare. Iaşi: Edit. Graphys, 399 pp.

IVĂNESCU L., TĂNASE C. \& MARDARI C. 2020. In memoriam. Academician Constantin Toma (1935-2020). Journal of Plant Development. 27: 199-207.

MARDARI C. \& TĂNASE C. 2016. Professor PhD Toader Chifu at the $80^{\text {th }}$ anniversary. Journal of Plant Development. 23: $227-228$.

MITITELU D. \& COSTICĂ M. 1993. Aniversalia. Prof. dr. Mandache Leocov la a 65-a aniversare. Buletinul Grădinii Botanice Iaşi. 4: 271-272.

MITITELU D. \& LEOCOV M. 1987. In memoriam. Botanistul Emilian Ţopa (1900-1987). Culegere de Studii și Articole de Biologie, Grădina Botanică Iaşi. 3: 317-319.

MITITELU D. \& TOMA C. 1983. In memoriam. Prof. dr. Constantin Burduja (1906-1983). Universitatea "Al. I. Cuza" Iaşi, Buletin iulie-decembrie. 147-148.

MITITELU D. \& TOMA C. 1988. In memoriam. Profesorul Constantin Papp (1896-1972). Analele Științifice ale Universității "Al. I. Cuza" Iaşi, s. II. a. Biologie. 34: 99-100.

MITITELU D. 1984. Aniversarea botanistului dr. Constantin Dobrescu. Analele Științifice ale Universității "Al. I. Cuza" Iaşi, s. II. a. Biologie. 30: 97-98.

MITITELU D. 1993. Prof. dr. Constantin Toma - membru corespondent al Academiei Române. Buletinul Grădinii Botanice Iași. 4: 261-262.

MITITIUC M. 1973. Micromicete din Grădina Botanică a Universităţii “Alexandru Ioan Cuza” Iaşi. Analele Științifice ale Universității "Al. I. Cuza" Iaşi, s. II. a. Biologie vegetală. 18(1): 135-140.

MITITIUC M. 1979. Micromicete din Grădina Botanică a Universităţii “Alexandru Ioan Cuza” din Iaşi. III. Culegere de studii şi articole de biologie. 1:143-147.

MITITIUC M. 1982. Micromicete din Grădina Botanică a Universităţii "Alexandru Ioan Cuza", nota VI. Analele Științifice ale Universității "Al. I. Cuza" Iaşi, s. II. a. Biologie vegetală. 28: 5-8.

MITITIUC M. 1982. Micromicete din Grădina Botanică a Universităţii "Alexandru Ioan Cuza" din Iaşi. V. Culegere de studii şi articole de biologie. (Lucr. simpozionului 125 ani de la înfintarea la Iaşi a primei Grădini Botanice din România). 2: 190-194.

MITITIUC M. 1984a. Ciuperci parazite pe o serie de specii ale genului Iris din Grădina Botanică a Universităţii "Alexandru Ioan Cuza" din Iaşi. Volum festiv, 150 de ani de la înfiinţarea Muzeului de Istorie Naturală Iaşi: 139-142.

MITITIUC M. 1984b. Micromicete din Grădina Botanică a Universităţii “Alexandru Ioan Cuza” din Iaşi. VI. Analele Științifice ale Universității “Al. I. Cuza" Iaşi, s. II. a. Biologie vegetală. 30: 58-60.

MITITIUC M. 1985. Micromicete din Grădina Botanică a Universităţii "Alexandru Ioan Cuza" din Iaşi. VII. Analele Științifice ale Universităţii “Al. I. Cuza” Iaşi, s. II. a. Biologie vegetală. 31: 71-74.

MITITIUC M. 1986a. Ciuperci parazite pe o serie de specii ale genului Rhamnus din Grădina Botanică a Universitătii "Alexandru Ioan Cuza" din Iaşi. Analele Științifice ale Universității "Al. I. Cuza” Iaşi, s. II. a. Biologie vegetală. 32: 42-43.

MITITIUC M. 1986b. Micromicete din Grădina Botanică a Universităţii “Alexandru Ioan Cuza" din Iaşi. VIII. Analele Științifice ale Universității “Al. I. Cuza” Iaşi, s. II. a. Biologie vegetală. 32: 50-53.

MITITIUC M. 1987a. Ciuperci parazite pe o serie de specii ale genului Berberis din Grădina Botanică a Universităţi "Alexandru Ioan Cuza" din Iaşi. Analele Științifice ale Universității "Al. I. Cuza" Iaşi, s. II. a. Biologie vegetală. 33: 39-42.

MITITIUC M. 1987b. Micromicete din Grădina Botanică a Universităţii “Alexandru Ioan Cuza” din Iaşi. IX. Culegere de studii şi articole de biologie. 3: 250-253.

MITITIUC M. 1989. Consideraţii asupra ciupercilor din clasa Ascomycetes din Grădina Botanică a Universităţii "Alexandru Ioan Cuza" din Iaşi. Analele Științifice ale Universităţii "Al. I. Cuza" Iaşi, s. II. a. Biologie vegetală. 35: 41-43.

MITITIUC M. 1991. Uredinale din Grădina Botanică a Universităţii "Alexandru Ioan Cuza" din Iaşi. Memoriile Secţilor Stitințifice ale Academiei Române. 14: 135-140.

MITITIUC M. 1992a. Sferopsidalele din Grădina Botanică a Universităţii "Alexandru Ioan Cuza” din Iaşi. Chişinău.

MITITIUC M. 1992b. Hifale din Grădina Botanică a Universităţii “Alexandru Ioan Cuza” Iaşi. Buletinul Grădinii Botanice Iaşi. 4: 104-108.

MITITIUC M. 1993. Consideraţii asupra ciupercilor din clasa Hyphomycetes din Grădina Botanică a Universităţii "Alexandru Ioan Cuza" din Iaşi. Buletinul Grădinii Botanice Iaşi. 4: 103-108. 
MITITIUC M. \& TONIUC A. 2006. Grădina Botanică “Anastasie Fătu” Iaşi. File de istorie. Iaşi: Edit. Universității "Alexandru Ioan Cuza", 160 pp.

MORARIU I. 1978-1980. Octogenarul Emilian Ţopa. Studii şi Comunicări, Muzeul de Ştiințe Naturale Bacău. 13: 261270.

OPREA A. 2013. Happy Anniversary, botanist dr. Ion Sârbu! Journal of Plant Development. 20: 163-164.

OPREA A. 2019. In memoriam. Professor dr. Dumitru Mititelu (1929-2005). Journal of Plant Development. 23: $207-$ 209.

POP E. 1967. Anastasie Fătu (1816-1886). In: Figuri de botanişti români. Bucureşti: Edit. Ştiinţifică, 128 pp.

ŞTEFUREAC T. 1979. Prof. dr. doc. Emilian Ţopa, Contribuţia sa la organizarea şi evoluţia Grădinilor Botanice Universitare din România. Culegere de Studii şi Articole de Biologie, Grădina Botanică Iaşi. 1: 51-64.

TĂNASE C. \& OPREA A. 2018. In memoriam. Professor univ. dr. eng. Mandache Leocov. Journal of Plant Development. 25: 165-167.

TĂNASE C. (ed.). 2012. In honorem: Profesorului Mihai Mititiuc la a 75-a aniversare. Iaşi: Edit. Universităţii "Alexandru Ioan Cuza", 149 pp.

TĂNASE C., COJOCARIU A. \& PETRE C. V. 2020. In memoriam. Professor Dr. Mihai Mititiuc (1937-2020) successor of mycological research in Iași. Journal of Plant Development. 27: 209-212.

TĂNASE C., TOMA C. \& BALAEŞ T. 2016. Anastasie Fătu - Founder of the Botanical Garden of Iași. Journal of Plant Development. 23: 3-14.

TOMA C. \& TONIUC A. 1984. In memoriam. Prof. dr. Constantin Burduja (1906-1983). Analele Științifice ale Universităţii “Al. I. Cuza” Iaşi, s. II. a. Biologie. 30: 99-100.

TOMA C. 2013. Botanist PhD Ion Sârbu at the $80^{\text {th }}$ anniversary. Analele Ştiințifice ale Universității "Al. I. Cuza" Iaşi, s. II. a. Biologie vegetală. 59(1): 53-55.

TOMA C. 2014. Botanist PhD Angela Toniuc celebrating her $70^{\text {th }}$ anniversary. Analele Științifice ale Universităţii “Al. I. Cuza" Iaşi, s. II. a. Biologie vegetală. 60(2): 83-86.

TOMA C. 2015. Biologi de altă dată şi de azi. Iaşi: Edit. Universității “Alexandru Ioan Cuza”, 453 pp.

TONIUC A. 2010. Profesorul dr. Constantin Toma şi grădina botanică ieșeană. In: IVĂNESCU L. \& ZAMFIRACHE M. M. 2010. In Honorem - Profesorului Constantin Toma la a 75 a aniversare. Iaşi: Edit. Graphys, 400 pp.

ZAMFIR G. 1987. Anastasie Fătu - om de cultură şi promotor al medicinei româneşti. Culegere de Studii şi Articole de Biologie, Grădina Botanică Iaşi. 3: 10-13.

ZANOSCHI V. \& TOMA C. 1995. Dimitrie Brandză (1846-1895). Studii şi Cercetări de Bioogie, (Biologie vegetală). 47(2): 171-175.

How to cite this article:

TĂNASE C., BÎRSAN C., COJOCARIU A., PETRE C. V. \& MARDARI C. 2021. Celebrating 165 years of collaboration between the Anastasie Fătu Botanical Garden and the natural science school from Iaşi. J. Plant Develop. 28: 3-21. https://doi.org/10.47743/jpd.2021.28.1.893 